\title{
Acute spinal cord syndrome secondary to venous congestion
}

Figure T2 and apparent diffusion coefficient sequence MRI cervical and upper thoracic spine
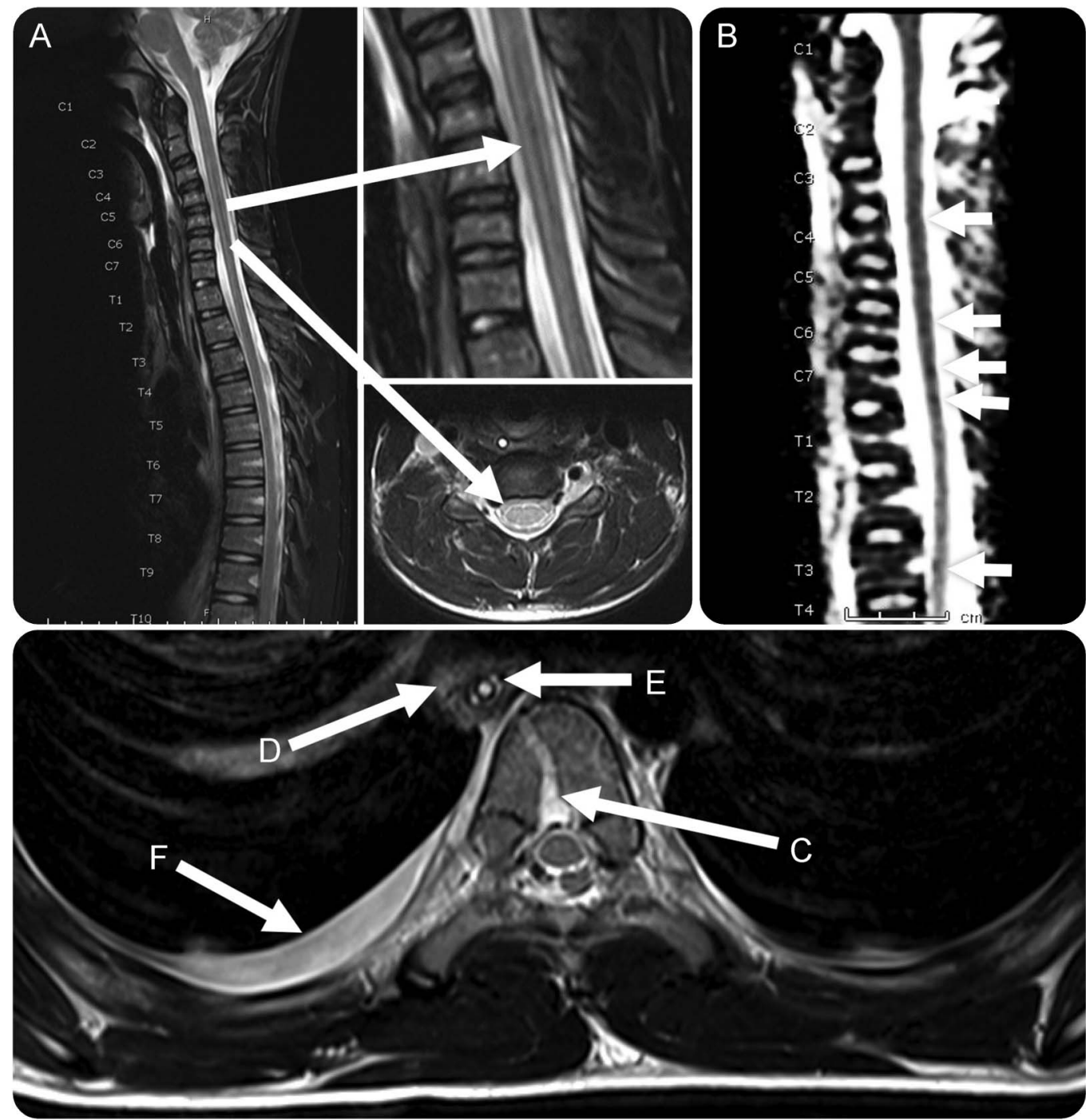

Evidence of subtle T2 hyperintensity throughout the spinal cord (A) with apparent diffusion coefficient changes (B) secondary to venous congestion of the basilar vertebral plexus (C). Associated mediastinitis (D) evidenced by thickened oesophageal wall (E) with intra-luminal nasogastric tube in situ, peri-oesophageal inflammation and pleural effusions $(F)$ is seen.

A 13-year-old boy developed lower limb flaccid paralysis 24 hours after accidental ingestion of an odorless and tasteless potassium hydroxide liquid. He had absent abdominal reflexes, brisk deep tendon reflexes, and no sensation distal to the umbilicus. MRI demonstrated T2 hyperintensities throughout the spinal cord and engorgement of basilar vertebral venous plexus (figure). He made a full recovery within 48 hours of empirical IV methylprednisolone.

Caustic ingestion can cause esophageal liquefactive necrosis and perforation leading to mediastinitis and venous congestion. ${ }^{1,2}$ Acute spinal cord syndrome secondary to venous congestion is an infrequently reported and poorly understood entity. 
From The Royal Children's Hospital, Melbourne, Australia.

Author contributions: Dr. Woodcock drafted the manuscript, edited the images for publication, and redrafted the manuscript. Dr. Coscini drafted the manuscript. Dr. Mandelstam selected the appropriate images for publication and revised the manuscript. Dr. Rodriguez-Casero revised the manuscript. Dr. Dabscheck conceptualized the study, revised the manuscript prior to submission, and supervised the process.

Study funding: No targeted funding reported.

Disclosure: The authors report no disclosures relevant to the manuscript. Go to Neurology.org for full disclosures.

Correspondence to I.R.Woodcock: ian.woodcock@rch.org.au

1. Contini S, Scarpignato C. Caustic injury of the upper gastrointestinal tract: a comprehensive review. World J Gastroenterol 2013;19:3918-3930.

2. Auler MA, Al-Okaili R, Rumboldt Z. Transient traumatic spinal venous hypertensive myelopathy. AJNR Am J Neuroradiol 2005;26:1655-1658.

\section{Help Redesign Neurology ${ }^{\circledR}$}

Read the September 6 issue of Neurology ${ }^{\circledR}$ featuring new short-form articles and give us your feedback by September 27.

http://tinyurl.com/Neurology2016.

\section{Subspecialty Alerts by E-mail!}

Customize your online journal experience by signing up for e-mail alerts related to your subspecialty or area of interest. Access this free service by visiting Neurology.org/site/subscriptions/etoc.xhtml or click on the "E-mail Alerts" link on the home page. An extensive list of subspecialties, methods, and study design choices will be available for you to choose from-allowing you priority alerts to cutting-edge research in your field!

\section{WriteClick ${ }^{\circledR}$ rapid online correspondence}

Have a comment on a recent $N$ eurology ${ }^{\circledR}$ article you would like to share? Now it is easier and more convenient. Neurology.org has launched WriteClick on the home page and sidebars of each article to encourage remarks and debate among users.

WriteClick is restricted to comments about studies published in Neurology within the last eight weeks.

Learn more at Neurology.org/letters 


\section{Neurology}

\section{Acute spinal cord syndrome secondary to venous congestion}

Ian R. Woodcock, Nadia Coscini, Simone Mandelstam, et al.

Neurology 2016;87;1302-1303

DOI 10.1212/WNL.0000000000003132

\section{This information is current as of September 19, 2016}

Updated Information \& Services

References

Subspecialty Collections

Permissions \& Licensing

Reprints including high resolution figures, can be found at: http://n.neurology.org/content/87/12/1302.full

This article cites 2 articles, 0 of which you can access for free at: http://n.neurology.org/content/87/12/1302.full\#ref-list-1

This article, along with others on similar topics, appears in the following collection(s):

All Pediatric

http://n.neurology.org/cgi/collection/all_pediatric

MRI

http://n.neurology.org/cgi/collection/mri

Other cerebrovascular disease/ Stroke

http://n.neurology.org/cgi/collection/other_cerebrovascular_disease_st roke

Other toxicology

http://n.neurology.org/cgi/collection/other_toxicology

Spinal cord infarction

http://n.neurology.org/cgi/collection/spinal_cord_infarction

Information about reproducing this article in parts (figures,tables) or in its entirety can be found online at:

http://www.neurology.org/about/about_the_journal\#permissions

Information about ordering reprints can be found online:

http://n.neurology.org/subscribers/advertise

Neurology ${ }^{\circledR}$ is the official journal of the American Academy of Neurology. Published continuously since 1951, it is now a weekly with 48 issues per year. Copyright () 2016 American Academy of Neurology. All rights reserved. Print ISSN: 0028-3878. Online ISSN: 1526-632X.

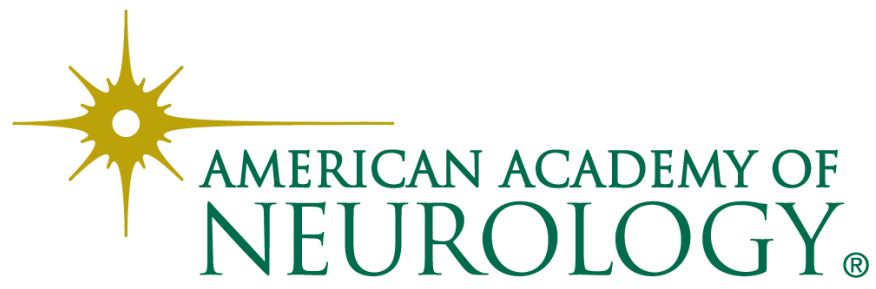

